\title{
Meningkatkan Hasil Belajar Siswa pada Operasi Hitung melalui Pendekatan Matematika Realistik
}

\author{
Jusmanidar \\ SDN 21 Batang Anai Kabupaten Padang Pariaman
}

\begin{abstract}
Abstrak
Mathematics learning at 2nd grade students of SDN 21 Batang Anai Kabupaten Padang Pariaman used to run traditionally; did not make connection between learning and real world. This is a classroom action research aimed to improve students' learning achievement for number operations by implementing realistic mathematics education (RME). This study consists of two cycles that includes four steps, i.e. planning, implementation, observation, and reflection. Data of this study were obtained through observation, interview, and test. Mean of students' learning achievement in cycle I is 77.2 and 88.2 in cycle II. Hence, it was concluded that implementation of RME can improve students' learning achievement, especially for topic of number operations.
\end{abstract}

Kata Kunci: Locus of Control, Student's Perception about Education, Learning Motivation Indonesian Institute for Counseling, Education and Therapy (IICET).

\section{PENDAHULUAN}

Matematika merupakan ilmu universal yang mendasari perkembangan teknologi modern, mempunyai peranan penting dalam berbagai disiplin dan memajukan daya pikir manusia. Matematika adalah mata pelajaran yang diajarkan pada setiap jenjang pendidikan di Indonesia mulai SD sampai dengan perguruan tinggi, untuk membekali siswa dengan kemampuan berfikir logis, analitis, sistematis, kritis, dan kreatif, serta kemampuan bekerjasama (Depdiknas, 2006). Kompetensi tersebut diperlukan agar siswa dapat memiliki kemampuan memperoleh, mengelola, dan memanfaatkan informasi untuk bertahan hidup pada keadaan yang selalu berubah, tidak pasti, dan kompetitif. Salah satu karakteristik matematika adalah mempunyai sifat yang abstrak, ini menyebabkan banyak siswa mengalami kesulitan dalam belajar matematika. Hal lain yang menyebabkan sulitnya matematika bagi siswa adalah karena pembelajaran matematika kurang bermakna, jadi pemahaman konsep yang benar sangatlah penting. Untuk memahami konsep yang baru, diperlukan prasyarat konsep sebelumnya agar pembelajaran matematika dimengarti oleh siswa, maka perlu penanaman konsep awal yang benar dari guru terutama guru SD.

Penyebab siswa kesulitan dalam matematika, dikarenakan guru kurang mengaitkan pembelajaran dengan kehidupan dalam kegiatan sehari-hari siswa dan kurang mengkonkretkan pembelajaran matematika sehingga siswa menganggap matematika itu sulit, terutama bagi siswa di kelas II SD yang harus paham tentang konsep-konsep matematika. Untuk menerapkan konsep matematika terutama materi operasi hitung campuran dalam kehidupan sehari-hari dapat dilakukan dengan strategi pembelajaran yang mengaitkan dengan dunia nyata sebagai titik tolak dalam belajar matematika, yang dikenal dengan pendekatan matematika realistik. Pembelajaran operasi hitung campuran dengan pendekatan matematika realistik, akan memberikan kesempatan kepada siswa 
untuk menemukan dan mengkonstruksi kembali konsep-konsep matematika sehingga siswa mempunyai konsep pengertian yang kuat.

Pembelajaran matematika haruslah bermakna bagi siswa, supaya siswa tidak mengalami kesulitan dalam mengaplikasikan matematika dalam situasi kehidupan nyata siswa. Guru dalam mengajar matematika di kelas harus mengaitkan pembelajarannya dengan skema yang telah dimiliki oleh siswa dan siswa harus diberikan kesempatan untuk menemukan kembali dan mengkonstruksi sendiri ide-ide matematika tersebut. Namun, dalam penyampaian pembelajaran matematika umumnya guru tidak mengaitkan dengan skema yang telah dimiliki oleh siswa dan siswa kurang diberikan kesempatan untuk menemukan kembali dan mengkonstruksi sendiri ide-ide matematika sehingga menyebabkan siswa belajar secara pasif. Konsekuensinya apabila siswa diberikan soal latihan yang berbeda dengan contoh soal, siswa sering membuat kesalahan dalam memberikan jawaban. Hal ini disebabkan karena guru memberikan satu contoh soal tanpa menambah dengan soal yang lain kemudian langsung memberikan soal latihan berbeda dengan contoh soal.

Dari pengalaman peneliti mengajar di kelas IIA ini, siswa mengalami kesulitan dalam belajar matematika yaitu tentang pembelajaran operasi hitung campuran, terutama yang berkaitan dengan perkalian dan pembagian. Pada saat guru menjelaskan pelajaran tersebut di depan kelas siswa mengerti, tapi bila siswa diberikan soal latihan yang berbeda siswa mengalami kesulitan dalam menyelesaikan soal tersebut. Seperti pada waktu guru menjelaskan pembelajaran tentang perkalian siswa mengerti setelah guru membuat soal pembagian dan perkalian dalam bentuk operasi hitung campuran siswa mulai bingung. Hal ini menyebabkan rendahnya hasil pembelajaran siswa. Hasil belajar adalah akibat yang ditimbulkan dari proses pembelajaran yang dilakukan pada diri siswa berupa kognitif, afektif, dan psikomotor. Hasil belajar matematika siswa dapat dilihat dari kemampuanya dalam mengingat pelajaran yang telah disampaikan selama pembelajaran yang dinyatakan dalam skor dari hasil tes dan bagaimana siswa tersebut bisa menerapkannya serta mampu memecahkan masalah yang timbul sesuai dengan apa yang telah dipelajarinya.

Hasil pembelajaran matematika juga tergantung pada bagaimana guru melaksanakan pembelajaran. Guru harus menciptakan pembelajaran yang menyenangkan bagi siswa. Salah satu cara yaitu dengan menerapkan pendekatan matematika realistik. Oleh sebab itu, perlu dikembangkan suatu pembelajaran yang tidak membosankan dan membuat siswa lebih tertarik, dengan cara menciptakan lingkungan belajar yang dekat dengan dunia nyata. Pendekatan matematika realistik adalah salah satunya. Dalam pendekatan matematika realistik, peran guru meliputi (a) sebagai fasilitator belajar; (b) membangun pengajaran yang interaktif; (c) memberikan kesempatan pada siswa untuk aktif pada proses belajar dan membantu siswa dalam menafsirkan persoalan riil; (d) tidak terikat pada materi yang ada dalam kurikulum, melainkan aktif mengaitkan kurikulum dengan dunia riil, baik fisik maupun sosial Sutarto (2005).

Kegiatan pembelajaran pendekatan matematika realistik dapat mengarahkan siswa mengaplikasikan teori matematika secara bermakna. Benda-benda konkret dan objek-objek lingkungan sekitar dapat digunakan sebagai konteks pembelajaran matematika dalam membangun keterkaitan matematika melalui interaksi sosial. Benda-benda konkret dimanipulasi oleh siswa dalam rangka menunjang usaha siswa dalam proses matematisasi konkret ke abstrak. Siswa perlu diberi kesempatan agar dapat mengkonstruksi dan menghasilkan matematika dengan cara dan bahasa mereka sendiri. Pembelajaran matematika dengan pendekatan matematika realistik, akan memberikan kesempatan kepada siswa untuk menemukan dan mengkonstruksi kembali konsep matematika sehingga siswa mempunyai konsep pengertian yang kuat. Hal tersebut dapat dilakukan dengan mengupayakan berbagai kondisi dan situasi serta permasalahan-permasalahan yang realistik, sehingga pembelajaran bermakna dan membuat siswa tertarik untuk belajar matematika serta dapat meningkatkan hasil pembelajaran.

\section{METODE PENELITIAN}

Jenis penelitian ini adalah penelitian tindakan kelas yaitu proses yang dilakukan perorangan atau kelompok yang menghendaki perubahan dalam situasi tertentu. Penelitian tindakan kelas 
adalah penelitian yang dilakukan oleh guru di dalam kelasnya sendiri melalui refleksi diri, dengan tujuan memperbaiki kinerjanya sebagai guru, sehingga hasil belajar siswa menjadi meningkat (Wardhani, 2007). Tempat penelitian dilaksanakan di SD Negeri 21 Batang Anai Kabupaten Padang Pariaman. Subjek dalam penelitian ini adalah siswa kelas II SD Negeri 21 Batang Anai dengan jumlah 25 siswa. Data penelitian berupa observasi, hasil tes, diskusi dan dokumentasi dari setiap tindakan perbaikan pembelajaran matematika melalui pendekatan matematika realistik siswa kelas II SD yang diteliti. Data tersebut berisi tentang hal-hal yang berkaitan dengan perencanaan, pelaksanaan, dan hasil pembelajaran.

\section{HASIL}

\section{Deskripsi Siklus I}

\section{Perencanaan}

Materi pembelajaran yang dilaksanakan pada siklus I ini berdasarkan kompetensi dasar melakukan operasi hitung campuran. Sebelum pelaksanaan pembelajaran terlebih dahulu penulis mempersiapkan rencana pelaksanaan pembelajaran, LKS, lembar evaluasi serta kunci jawaban evaluasi yang akan digunakan dalam pembelajaran. Di samping itu, penulis juga menyiapkan lembar pengamatan yang akan diberikan pada observer (guru kelas) untuk mengamati jalannya pembelajaran tentang operasi hitung campuran dengan menggunakan pendekatan matematika realistik. Komponen akhir perencanaan pembelajaran ini adalah evaluasi proses dan evaluasi hasil. Evaluasi proses yang direncanakan adalah mengamati aktivitas siswa secara individu dalam melaksanakan kegiatan pembelajaran. Evaluasi hasil adalah melihat hasil perolehan siswa dalam menjawab pertanyaan secara individual.

\section{Pelaksanaan}

Tindakan pada siklus I ini dilakukan dalam dua kali pertemuan. Pelaksanaan pembelajaran dilakukan dalam empat tahapan pendekatan matematika realistik, yaitu tahap pendahuluan, tahap pengembangan model simbolik, tahap penjelasan dan alasan, serta tahap penutup.

\section{Pengamatan}

\section{a. Aktivitas Guru}

Guru membangkitkan skemata siswa melalui tanya jawab tentang masalah sehari-hari siswa, yang berkaitan dengan operasi hitung. Selanjutnya guru menyebutkan tujuan pembelajaran. Selanjutnya guru membagi siswa dalam 5 kelompok. Siswa melakukan petunjuk yang ada pada LKS. Guru mengarahkan siswa untuk mencari penyelesaian masalah yang terdapat pada LKS dengan caranya sendiri dengan berdiskusi dalam kelompok. Selanjutnya siswa memulai kegiatan menyelesaikan masalah yang ada pada LKS dengan berdiskusi dalam kelompoknya. Guru mengarahkan siswa untuk aktif bekerja dalam kelompok. Setelah semua kelompok selesai mengerjakan LKS, guru meminta siswa untuk melaporkan hasil diskusinya ke depan kelas. Kelompok yang tampil diminta untuk menjelaskan model yang mereka pakai dalam menyelesaikan masalah yang ada pada LKS. Kemudian kelompok lain memberikan tanggapan kepada kelompok yang tampil. Pada kegiatan akhir, guru membimbing siswa untuk menyimpulkan pembelajaran tentang operasi hitung. Selanjutnya siswa diberikan tes akhir. Tes akhir dilakukan bersama-sama dalam kelas secara individual. Soal diberikan dalam bentuk esai.

\section{b. Aktivitas Siswa}

Siswa masih belum aktif untuk mengikuti pembelajaran, hal ini dapat dilihat siswa masih belum maksimal menanggapi pertanyaan yang diberikan oleh guru dengan baik. Siswa bekerja dalam kelompok dengan baik tetapi tidak semua siswa yang serius, ini terlihat dengan banyaknya siswa yang bermain-main saat berdiskusi. Dalam melakukan diskusi masih didominasi oleh siswa yang pintar, begitu juga dalam mengisi LKS hanya diisi oleh satu orang saja. Pada saat siswa disuruh melaporkan hasil diskusi, siswa kurang antusias ke depan kelas karena malu untuk melaporkan hasil diskusinya. Siswa masih malu-malu dalam mengemukakan pendapatnya, ini terlihat saat menanggapi laporan hasil diskusi hanya satu siswa saja yang berani menanggapi. Hal ini membuktikan siswa belum aktif untuk mengikuti belajar. 


\section{Hasil Belajar}

Observasi keberhasilan tindakan diamati selama dan sesudah tindakan dilaksanakan. Hal ini dilaksanakan untuk mendapatkan informasi dari observer terhadap pelaksanaan pembelajaran pada siklus I, baik pelaksanaan, evaluasi dan hasil yang diperoleh oleh siswa. Berdasarkan pengamatan para observer, pada tindakan siklus I ditemukan masih ada siswa yang belum ikut secara aktif menyelesaikan masalah realistik yang diberikan. Selain itu juga ditemukan adanya beberapa siswa yang belum berani mengemukakan pendapatnya, siswa lebih suka mendengar dan memperhatikan temannya berdiskusi. Keadaan kelas memang agak ribut dan waktu banyak terbuang untuk mengatur siswa. dan siswa masih ada yang belum aktif mengikuti kegiatan pembelajaran secara individual dan pada kelompoknya. Namun demikian, secara umum ditemukan bahwa siswa secara klasikal senang belajar dengan pendekatan realistik.

Siswa lebih cepat memahami masalah dengan adanya kegiatan dan kebebasan dalam bekerja. Apalagi siswa diberi kesempatan bertanya dan memperhatikan kelompok lain untuk menyampaikan hasil evaluasi dan LKSnya. Dalam pembelajaran siswa terlihat senang jadi tidak mengantuk dan waktupun terasa cepat berlalu, sehingga tidak menimbulkan kejenuhan. Evaluasi hasil yang diperoleh pada siklus I mencapai 77,2\%. Hal ini disebabkan ada sebagian yang siswa masih mengalami kesulitan dalam menjawab soal mengenai perkalian dan pembagian dan mengenai operasi hitung campuran dalam pembelajaran melalui pendekatan matematika realistik.

\section{Refleksi}

Kegiatan refleksi dilakukan secara kolaboratif antara peneliti dengan observer setiap pembelajaran berakhir. Refleksi tindakan siklus I ini mencakup refleksi terhadap perencanaan, pelaksanaan, evaluasi dan hasil yang diperoleh oleh siswa. Secara umum pelaksanaan pembelajaran telah berjalan sesuai dengan rencana pembelajaran yang disusun karena telah mencerminkan model pendekatan realistik. Belum semua siswa aktif, maka aktifitas siswa selama proses pembelajaran perlu ditingkatkan. Guru perlu meningkatkan cara memotivasi siswa dalam mengeluarkan pendapat karena masih banyak siswa yang belum berani menanggapi hasil diskusi kelompok temannya.

Guru perlu membimbing siswa dalam menyimpulkan materi pembelajaran karena siswa banyak yang tidak membuat kesimpulan materi pelajaran. Pembelajaran siklus I memerlukan waktu lebih dari waktu yang direncanakan, karena waktu banyak terpakai oleh pengaturan kelompok. Pelaksanaan pembelajaran masih belum optimal, karena masih ada siswa yang belum paham memindahkan permasalahan kebentuk matematika. Hasil tes akhir dan ketuntasan belajar siswa menunjukan lebih dari separoh siswa yang belum tuntas belajarnya. Masih ada beberapa siswa yang masih mendapatkan nilai di bawah rata-rata. Pada umumnya siswa mengalami kesulitan dalam langkah melakukan operasi hitung campuran. Setelah ditanyakan kepada siswa ternyata banyak yang menjawab tidak paham yang mana yang dikerjakan terlebih dahulu.

\section{Deskripsi Siklus II}

\section{Perencanaan}

Hasil analisis refleksi pada siklus I menunjukkan keberhasilan penelitian belum mencapai tujuan yang diharapkan, hal ini dikarenakan karena kurangnya sistematika dalam pelaksanaan dengan perencanaan yang telah dibuat. Karena itu pembelajaran dilanjutkan dengan siklus II. Berdasarkan refleksi dari siklus I, maka untuk peningkatan aktivitas dan hasil belajar siswa agar sesuai dengan yang diharapkan, pada siklus II direncanakan hal-hal sebagai berikut: memotivasi siswa agar aktif berdiskusi dalam kelompok; untuk menghemat waktu, siswa dikelompokan dengan teman sebangkunya dan ini juga bertujuan supaya siswa lebih aktif dalam melakukan kegiatan; lebih membimbing siswa untuk paham memindahkan permasalahan ke bentuk matematika; memotivasi siswa untuk menanggapi hasil diskusi kelompok temannya; dan membimbing siswa menyimpulkan materi pelajaran. 


\section{Pelaksanaan}

Pelaksanaan pada siklus II serupa dengan apa yang dilaksanakan pada siklus I. Tindakan pada siklus II ini dilakukan dalam dua kali pertemuan. Pelaksanaan pembelajaran dilakukan dalam empat tahapan pendekatan matematika realistik, yaitu tahap pendahuluan, tahap pengembangan model simbolik, tahap penjelasan dan alasan, serta tahap penutup.

\section{Pengamatan}

\section{a. Aktivitas Guru}

Mula-mula guru memberikan beberapa soal dengan kartu matematika dan tabel perkalian dan pembagian sebelum siswa diminta mengerjakan latihan. Setelah siswa mengerti, masingmasing siswa mengerjakan latihan yang diberikan guru. Siswa yang masih kurang mamahami petunjuk pada latihan yang diberikan guru diberikan kesempatan untuk bertanya. Setelah siswa paham dengan pedoman kerja yang ada dalam latihan, dari penjelasan yang diberikan guru tentang pedoman kerja pada latihan tersebut. Kemudian guru meminta siswa untuk mengerjakan latihan tersebut.

Setelah siswa mengerjakan petunjuk yang ada pada evaluasi, guru mengarahkan siswa untuk mencari penyelesaian masalah yang terdapat pada evaluasi dengan caranya sendiri. Masalah yang dibahas dalam pertemuan ini sama pada siklus I, yaitu melakukan perkalian dan pembagian dengan memberiakn soal yang berbeda. Setelah semua siswa selesai mengerjakan evaluasi, seperti pada siklus I guru meminta siswa untuk melaporkan hasil evaluasinya ke depan kelas. Siswa yang tampil diminta untuk menjelaskan model yang mereka pakai dalam menyelesaikan masalah yang ada pada evaluasinya. Kemudian siswa yang lain memberikan tanggapan kepada siswa yang tampil. Pada kegiatan akhir, guru membimbing siswa untuk menyimpulkan pembelajaran tentang perkalian dan pembagian. Tes evaluasi dilakukan bersama-sama dalam kelas secara individual.

\section{b. Aktivitas Siswa}

Semua siswa serius mengikuti kegiatan diskusi dalam menyelesaiakan tugas yang diberikan oleh guru tentang cara melakukan operasi hitung campuran perkalian dan pembagian bilangan dua. Siswa termotivasi dalam menyelesaikan evaliuasi dan LKS yang telah dibagikan. Siswa nampak senang dalam bekerja. Siswa sudah berani dan bersemangat dalam mempresentasikan hasil diskusi kelompoknya meskipun melalui bimbingan gurunya. Siswa sudah aktif bekerja dalam kelompok. Siswa sudah membuat kesimpulan materi pelajaran. Tes akhir yang diberikan guru diselesaikan siswa tanpa mengalami kesulitan. Hal ini membuktikan siswa aktif untuk mengikuti belajar.

\section{c. Hasil Belajar}

Evaluasi hasil yang diperoleh pada siklus II mencapai rata-rata $88 \%$ dengan perincian sebagai berikut: 8 siswa (32\%) yang memperoleh nilai 100, 6 siswa (24\%) yang meperoleh nilai 90, 5 siswa (20\%) yang memperoleh nilai 85,3 pserta didik (12\%) yang memperoleh nilai 80,2 siswa (8\%) yang mendapat nilai 70,1 siswa $(4 \%)$ yang memperoleh nilai 60 . Ini berarti lebih dari $85 \%$ dari jumlah siswa yang mendapat nilai diatas 75 (88\% dari jumlah siswa). Evaluasi hasil yang diperoleh pada siklus II $(88,2)$ mengalami peningkatan dibandingkan dengan tes pada siklus I $(77,2)$.

\section{Refleksi}

Refleksi terhadap perencanaan yakni sebagai berikut: dilihat dari paparan siklus II diketahui bahwa perencanaan pembelajaran sudah lebih baik dari siklus I, serta dilaksanakan sesuai dengan langkah-langkah yang tertulis dalam perencanaan. Dari hasil belajar siswa sudah meningkat, karena tidak ditemukan lagi siswa yang memperoleh nilai dalam $<70$. Nilai anak hanya berkisar di atas 70-100 dengan nilai rata-rata siswa 88. Dengan demikian, dapat disimpulkan bahwa penelitian dalam pembelajaran siklus II telah melaksanakan tugas dengan baik. Hal ini dapat dilihat pada lampiran yaitu hasil belajar siswa pada siklus II. Dengan demikian penelitian ini berhenti pada siklus II dan tidak dilanjutkan pada siklus berikutnya. 


\section{PEMBAHASAN}

\section{Siklus I}

Pelaksanaan pembelajaran pada siklus I dilaksanakan sesuai dengan apa yang telah direncanakan, yaitu dua kali pertemuan. Pembelajaran pada siklus I dilaksanakan sesuai dengan tahap-tahap pembelajaran matematika realistik yang meliputi tahap pendahuluan, tahap pengembangan model simbolik, tahap penjelasan dan alasan, dan tahap penutup. Berdasarkan catatan pada lembar observasi dan diskusi peneliti dengan pengamat, penyebab dari masih rendahnya hasil belajar siswa pada siklus I secara garis besar adalah masih banyak siswa yang belum aktif dalam pembelajaran. Setelah diperhatikan data hasil penelitian yang berkaitan dengan evaluasi pembelajaran, evaluasi yang dilakukan adalah evaluasi proses dan evaluasi hasil. Evaluasi proses pada setiap siklus dilakukan guru pada saat siswa berdiskusi.

Dari hasil observasi aktivitas guru dan siswa serta diskusi peneliti dengan observer, penyebab dari adanya siswa yang belum dapat menyelesaikan operasi hitung campuran disebabkan karena pembelajaran yang kurang menyenangkan dan guru kurang mengkonkretkan pembelajaran serta kurang melibatkan siswa dalam kegiatan pembelajaran operasi hitung campuran. Berdasarkan hasil pengamatan aktivitas guru, guru kurang memberikan motivasi kepada siswa untuk menyampaikan ide/gagasan yang ditemukannya. Guru juga kurang membimbing siswa dalam menyimpulkan materi pelajaran. Oleh sebab itu sebaiknya guru lebih memotivasi dan membimbing siswa untuk menyampaikan ide/gagasan yang mereka temukan dalam melakukan operasi hitung campuran. Guru harus membimbing siswa untuk membuat simpulan pembelajaran dan membimbing siswa untuk dapat memindahkan permasalahan dalam matematika. Hal ini karena siswa baru pertama kali melaksanakan pembelajaran seperti ini.

\section{Siklus II}

Rencana Pelaksanaan Pembelajaran (RPP) pada siklus II ini hampir sama dengan siklus I, namun dalam tahap penyelidikan, pengembangan materi, media yang digunakan dalam penyelidikan lebih dimaksimalkan. Pembelajaran melakukan operasi hitung campuran perkalian dan pembagian bilangan sampai dua angka dengan menggunakan pendekatan matematika realistik pada siklus II ini sudah berjalan dengan baik. Pembelajaran dipengaruhi oleh berbagai faktor seperti motivasi, kematangan, hubungan siswa dengan guru, kemampuan verbal, tingkat kebebasan, rasa aman, dan keterampilan guru dalam berkomunikasi. Oleh karena itu, guru harus melakukan perbaikan dalam pelaksanaan pembelajaran disamping perbaikan pada RPP. Guru harus dapat memberikan motivasi kepada siswa dalam pembelajaran. Peran guru dalam membelajarkan siswa sangat besar, upaya menimbulkan motivasi anak untuk belajar sangat berat. Dari hasil analisis penelitian siklus II sudah mencapai $88 \%$ dan nilai rata-rata kelas 88,2. Berdasarkan hasil pengamatan siklus II yang diperoleh, maka pelaksanaan siklus II sudah baik dan guru sudah berhasil dalam usaha peningkatan hasil belajar matematika tentang operasi hitung campuran melalui pendekatan realistik bagi kelas II SDN 21 Batang Anai Kabupaten Padang Pariaman.

\section{KESIMPULAN}

Dalam pembelajaran matematika dengan pendekatan realistik, siswa dituntut untuk berperan aktif dalam pembelajaran dan terlibat selama proses pembelajaran. Guru hanya berperan sebagai fasilitator bagi siswa dalam proses rekonstruksi ide dan konsep matematika. Siswa bebas mengeluarkan ide yang dimilikinya dalam membuat keputusan yang benar dan mudah dipahami. Ada tiga prinsip utama dalam pembelajaran matematika realistik, yaitu (1) penemuan terbimbing dan matematisasi progresif (guided reinvention and progresive mathematizing); (2) fenomeologi didaktis (didactical phenomenology), siswa dalam mempelajari matematika harus dimulai dari masalah-masalah kontekstual yang terdapat dalam kehidupan sehari-hari; (3) self develoved models, prinsip ini merupakan jembatan antara pengetahuan matematika informal dengan formal dari siswa, kemudian siswa diberi kesempatan untuk mengembangkan model-modelnya sendiri (Gravemeijer, 1994).

Pendekatan realistik dapat memotivasi siswa untuk belajar dengan gembira, bebas, aktif, dan produktif, sehingga kendala psikologis yang sering menghambat siswa seperti rasa enggan, segan, 
takut, dan malu dapat teratasi. Siswa terlatih berbagi pengalaman, aktif dalam belajar, berani menyampaikan ide/gagasan yang ditemukannya, dan bersedia mendengarkan pendapat orang lain, serta mau menerima perbedaan pendapat. Fungsi guru berubah dari seorang penyampai pengetahuan atau pemberi informasi menjadi fasilitator. Hal ini terlihat dalam penyajian pembelajaran guru yang semula selalu memberi penjelasan berubah menjadi fasilitator. Bentuk pembelajaran dengan pendekatan realistik terhadap operasi hitung campuran dapat meningkatkan hasil belajar siswa. Meningkatnya hasil belajar siswa tersebut dapat dilihat dari rata-rata yang diperoleh pada siklus I yakni 77,2 dan pada siklus II mengalami peningkatan yaitu menjadi 88,2.

\section{SARAN}

Bentuk pembelajaran matematika melalui pendekatan realistik layak dipertimbangkan oleh guru untuk menjadi pembelajaran alternatif yang dapat digunakan sebagai referensi dalam memilih pendekatan pembelajaran. Bagi guru yang ingin menerapkan pembelajaran dengan menggunakan pendekatan realistik, disarankan memperhatikan hal-hal sebagai berikut: materi pembelajaran disesuaikan dengan konteks sehari-hari siswa; perlu lebih kreatif dalam merancang pembelajaran yang sesuai dengan situasi dunia nyata; serta perlu memberikan perhatian, bimbingan dan motivasi belajar secara sungguh-sungguh kepada siswa yang berkemampuan kurang dan pasif dalam kelompok, karena siswa yang demikian sering menggantungkan diri pada temannya.

\section{DAFTAR RUJUKAN}

Arikunto, Suharsimi dkk. 2010. Penelitian Tindakan Kelas. Jakarta: Bumi Aksara.

Depdiknas. 2006. Kurikulum Tingkat Satuan Pendidikan Jenjang Pendidikan Dasar. Jakarta: Depdiknas.

Gravemeijer. 1994. Developing Realitics Mathematics Education. Utrecht: Freudenthal Institute.

Sutarto, Hadi. 2007. Pendidikan Matematika Realistik. Banjarmasin: Tulip. 